\title{
Implementation of Technology Transfer in Mass Rapid Transport (MRT) Project in Malaysia
}

\author{
Roshartini Omar ${ }^{1 *}$, Tan Khai Hua ${ }^{1}$, Aina Mardia Sallehuddin ${ }^{1}$, Norliana Sarpin ${ }^{1}$. Mohd Yamani Yahya ${ }^{1}$, Goh Kai Chen ${ }^{1}$, \\ Sulzakimin Mohamed ${ }^{1}$ and Md Asrul Nasid Masrom¹. \\ ${ }^{1}$ Department of Construction Management, Faculty of Technology Management and Business, Universiti Tun Hussein Onn Malaysia \\ (UTHM), Johor, Malaysia
}

\begin{abstract}
Technology transfer is a useful resource for improving technology and it is widely used in various industrial fields. The application of technology transfer in the construction industry can be viewed via the Mass Rapid Transit (MRT). The transfer of technology has been implemented in the construction of the MRT but there are a number of factors and barriers in implementing as well. Therefore, this study attempts to understand the technology transfer in the MRT project in the country and study the factors that influence the process of technology transfer in the MRT project. Data collection was conducted through interviews with respondents involved in technology transfer MRT project namely MRT Corporation Sdn. Bhd. And MMC-Gamuda KVMRT (PDP) Sdn. Bhd. The results showed organisational capabilities, relational capabilities, communications, level of absorptive capacity and technological capabilities, development of skilled human resources and economic advancement are factors that influenced the transfer of technology in MRT project. The findings of this study can be used as a guide for the MRT project in the future to avoid failure in the technology transfer.
\end{abstract}

\section{Introduction}

Technology transfer is the process of transferring or sharing skills and knowledge from one people or one place to another. Technology transfer which is a useful source for technology improvement is widely used in various industry fields [1]. Technology transfer also being applied in construction industry. This can be clearly seen from Mass Rapid Transit (MRT). MRT is a public transport which requires high and complicated technology.

Technology transfer in Mass Rapid Transit (MRT) is a wise step in controlling the air pollution issue and traffic jam issue in Malaysia For the last few decades, technology transfer from a developed country was viewed as a solution for technology development of developing country [2,3]. According to a study, developed country such as United Stated of America, United Kingdom and Germany are the leading country in technology transfer research [4]. Technology which is invented successful will be transferred to the developing country to enhance the knowledge of the people in their respective field.

\subsection{Research Problems}

According to [5], the purpose of technology transfer is to improve productivity at project, firm and industry level and benefit to economic growth in the host country in the long term. In recent years, Malaysia had started the first
MRT project in order to accommodate increasing number of residents in Kuala Lumpur area. Global market leader in mechanized tunnelling technology, developed a new type of machine for Klang Valley MRT project to complete the tunnelling process [6]. Furthermore, Mitsubishi Heavy Industries Ltd was in charge of the design and engineering, procurement and installation of track works for Klang Valley MRT project [7]. These showed that various advanced technologies used in constructing the MRT project were mainly transferred from other developed countries.

Rapid industrialisation can be credited to technology transfer [5]. However, a successful technology transfer faced a lot of challenges and is not an easy process. [8] highlighted that poor financial system, human resource constraints and limited or inability to adopt technology is the problem faced by most of the company in Malaysia. Another researcher who studied barriers in technology transfer in India concluded that lack of skills, capability and financial support are the reasons that obstructed technology transfer [9]. Expensive infrastructure and price competition with other competitors from other countries such as Indonesia, China, Thailand and India are also among the factors that caused failure in technology transfer [10].

Challenges and barriers are also faced in technology transfer in Malaysia's MRT project. In the process of transferring technology in MRT project, the construction firms met barriers which caused unavoidable delay in

\footnotetext{
* Corresponding author: shartini@uthm.edu.my
} 
time of completion and increasing in cost of project, claimed by MRT Corp [11]. [12] reported that there were few cases of fatal accidents happened in 2-year time in the construction process of Klang Valley MRT project. The above showed that even though technologies were transferred from other countries into Malaysia's MRT project, the construction work still faced problems such as delay in completion time and increasing cost of construction.

\section{Technology Transfer}

Technology transfer is the process of transferring or sharing skills and knowledge from one people or place to another. Technology transfer which is a useful source for technology improvement is widely used in various industry fields [1]. Technology transfer is embedded in the current phenomenon of growth in a global economy and is the market-driven process by which innovations are adopted and implemented [12]. The components of technology transfer consist of transferring of skills, technical knowledge, machinery, soft skills and equipment [13].

In most cases, technology transfer requires physical processes related to knowledge (physical elements such as digital components) as well as know-how or advanced skills on instalments. Technology transfer can be enhanced if theory is accurately applied by the practitioner and researchers [14]. Besides that, successful technology transfer depends largely on technology, ownership, transfer, purpose, specialist, environment, timing and process [15].

Hence, in this study, technology transfer is defined as the process of technology, knowledge and equipment in MRT project which are transferred from a developed country to a developing country namely tunnelling skills or tunnelling machines in MRT project

\subsection{Case Study of Technology Transfer in MRT in Various Countries}

MRT is a common public transport in many developed and developing countries. In this study, MRT system from both developed and developing countries such as Japan, Taiwan, Indonesia and Philippines were discussed. Types of technology transfer used in the countries, factors influencing the process and the barriers were discussed. This is to have a background and concept for technology transfer process which are applicable to this study.

\subsubsection{Technology Transfer in Japan MRT}

Rail transport in Japan began in 1872 and Japan was considered one of the oldest countries to apply rail transport system. In recent years, to improve the safety and stability of the rail transport system, many advance features have been added into the current Japan's rail transport system such as wireless train [16]. Engineers in Japan used technological developments such as innovative tunnelling techniques and tilting carriages that permit higher speeds through curves [17]. Besides that, as stated by [18], Trans-Kawasaki Expressway Route in Japan applied multi-micro shield tunnelling (MMST) method.

Japan as one of the leaders in advance MRT system often transfers the technology to the developing countries such as Malaysia. One of the examples is Mitsubishi Heavy Industries Ltd in Malaysia MRT project. Mitsubishi Heavy Industries Ltd is a Japan company which in charge of the design and tunnelling method in Malaysia latest MRT project [18].

\subsubsection{Technology Transfer in Taiwan MRT}

Taipei Mass Rapid Transit (MRT) system started construction 26 years ago and the average daily passengers were more than 190 thousand people. It currently has a comprehensive and expanding MRT network comprising of approximately $121.3 \mathrm{~km}$ operational length, 11 lines and 109 MRT stations [19]. Due to the increasing economic growth and increasing population mobility in Taiwan, the demand for transportation increase significantly, resulting in increasing energy use in the transport sector [20] and increasing greenhouse gas emissions and air pollution, seriously damaging the environment [21].These are the driving force for the application of MRT in Taiwan.

Advance technology that transferred into Taiwan can be clearly seen from the tunnelling system. In the construction of Taoyuan International Airport Access (TIAA) MRT, Double-O-Tube shield tunnelling was introduced [22]. Furthermore, [23] found out that floating slab track, the best anti-vibration solution of the track system for high-speed railroad, traditional railroad, urban track transport, and light rail transportation were applied in Taiwan's MRT.

\subsubsection{Technology Transfer in Philippines MRT}

Manila Light Rail Transit System of Philippines was constructed in the early 1980s. The system was designed to carry in excess of 23,000 passengers per hour per direction and able to accommodate 48,000 passengers per hour, per direction. The method is of European technology and is widely used worldwide. According to Tomas [24], the increasing population act as a catalyst for improving the MRT system in Philippines. Improved MRT system is required to accommodate the increasing population in Philippines.

In the Philippines, the Megatren Line 2 project pioneered the use of the pre-casting segmental method (PSM) technology or the pre-casting of the girders into smaller segments so that each span connected between two columns is weighing not more than 58 tons. This is a special method used in building the viaduct or the long stretch of suspension bridges resting on the concrete towers [25]. According to [25], the origin of PSM technology is Germany and this clearly shown that technology was transferred from Germany to Philippines. 


\subsubsection{Technology Transfer in Indonesia MRT}

Jakarta Mass Rapid Transit (Jakarta MRT) is a rapid transit system which is currently under construction in Jakarta, the capital city of Indonesia. According to [26], Jakarta MRT will be completed in year 2017 and start operating in the first quarter of the following year. According to 27], relieve serious traffic issue is the major factor for Indonesia's government to apply technology transfer to construct MRT system in Indonesia.

A consortium of Shimuzu, Obayashi, Wijaya Karya, and Jaya Construction will be responsible for two packages and a joint-venture of Sumitomo Mitsui Construction and Hutama Karya won the third contract of the MRT project, reported by [28]. Earth pressure type shield machine, a technology from Japan, is used in the construction of Jakarta MRT to minimize the effect on the existing surface and a new excavation method is introduced. Automatic Train Protection systems, Platform Screen Doors and Automatic Fare Collection are the modern design of Jakarta MRT [27].

\section{Research Methodology}

This study is focus on how technology transfer in Malaysia MRT project can be improved by identifying the type of technology that transferred, factors influencing and barriers in implementation of technology transfer in Malaysia MRT project. Klang Valley MRT project is the first and ongoing underground MRT project in Malaysia which owned by MRT Corporation Sdn. Bhd. (MRT Corp) with MMC-Gamuda KVMRT (PDP) Sdn. Bhd. as the Project Delivery Partner (Land Public Transport Commission, 2010). This study is focus on Klang Valley MRT project because the two companies are heavily involved in technology transfer and hence feedback from the two companies would be able to fulfil these research objectives. In order to obtain the most accurate findings for this study, employees such as project manager, safety manager and public relation executives who have experience in technology transfer in MRT project unquestionably are chosen as the respondents. Interview by means of semi structured interview with experienced respondents will be conducted in order to obtain more accurate and useful response on technology transfer.

The population in this study are the MRT Corp who is the owner of the Klang Valley MRT Project. Furthermore, MMC-Gamuda KVMRT (PDP) Sdn. Bhd. who is the Project Delivery Partner of MRT Corp is also the target group for this study. The sample of this study consisted of the employees who are experienced in technology transfer from both from MRT Corp and MMC-Gamuda KVMRT (PDP) Sdn. Bhd. Three experienced employees from MRT Corp - project manager, safety manager and public relation executive are the respondents for this study. Besides that, head of public relation department and public relation manager of MMC-Gamuda KVMRT (PDP) Sdn. Bhd. have also helped in answering questions for this study. Only five respondents are able to involve in this study. However, all the respondents have great experiences in technology transfer in Klang Valley MRT project are chosen based on inductive logic of research in a qualitative study.

\section{Results and Discussion}

\subsection{Factor Influencing Technology Transfer in Malaysia's MRT Project}

Based on data analysis results, technology transfer which is beneficial for the MRT project does not have any disadvantages. Benefits of technology transfer in MRT project include additional skillsets for the organisation, improving quality and productivity of construction work in MRT project. Technology transfer allows employees to learn new knowledge for MRT construction which are difficult to learn from books. With the additional skill sets of employees, a safer and more efficient MRT project can be achieved and the organisation will have a better position in the market.

However, there are a lot of factors that influenced technology transfer in MRT project such as organisation capability, relational capability, communication, levels of absorptive capacity and technological capability, development of skilled human resources and economic advancement as. Technology transfer can be affected by some preventive and contingent factors which are awareness of needed radical factors to transfer of past technology transfer success or failures. Factors influencing technology transfer in Malaysia's MRT project with short explanation are shown in Table 1.

[29] commented that good relationship or any increase in cooperation between two parties would cause the transfer of knowledge. Good relationship between parties who involved in technology transfer is important for the success of technology transfer. Both parties have to follow Terms and Conditions which are specified in the contract throughout the technology transfer process. In this case, arguments and disbelieve between two parties can be avoided. This can enhance the relationship between transferor and transferee in order to smoothen the technology transfer process and ensure the successful completion of technology transfer.

Communication can be defined as the flow of messages and common understanding from one person to another [30]. Communication plays an important role in influencing technology transfer in MRT project because technology transfer involves conversation and transferring of knowledge. Without a similar language and good communication skills, the meaning of messages might be distorted and changed.

Furthermore, technology transfer is also affected by the absorptive capacity and technology capabilities dimensions. Absorptive capacity as a dynamic capability can be analysed on macro and micro levels and exists on national, regional, organisational and individual levels. Matching level of capabilities between two parties is important to allow technology transfer to take places in MRT project. Without similar knowledge level between the two parties, technology transfer is difficult to carry out because one of the parties might not able to 
understand technologies that are transferred in MRT project

Table 1: Factor Influencing Technology Transfer in Malaysia's MRT Project

\begin{tabular}{|l|l|l|l|l|l|}
\hline & \multicolumn{1}{|c|}{$\mathbf{R 1}$} & \multicolumn{1}{|c|}{$\mathbf{R 2}$} & \multicolumn{1}{c|}{ R3 } & \multicolumn{1}{c|}{ R4 } & \multicolumn{1}{|c|}{ R5 } \\
\hline Organisational Capability & $\begin{array}{l}\text { Capital funding } \\
\text { Manpower } \\
\text { training }\end{array}$ & Good planning & $\begin{array}{l}\text { Capital funding } \\
\text { Well-structured }\end{array}$ & $\begin{array}{l}\text { Good decision } \\
\text { making }\end{array}$ & Maximum return \\
\hline Relational Capability & $\begin{array}{l}\text { Terms and } \\
\text { conditions in } \\
\text { contract }\end{array}$ & $\begin{array}{l}\text { Good } \\
\text { relationship }\end{array}$ & $\begin{array}{l}\text { Good } \\
\text { relationship }\end{array}$ & $\begin{array}{l}\text { Acceptance and } \\
\text { willingness }\end{array}$ & $\begin{array}{l}\text { Good } \\
\text { relationship }\end{array}$ \\
\hline Communication & Message distorted & $\begin{array}{l}\text { Difficult to } \\
\text { have discussion }\end{array}$ & $\begin{array}{l}\text { Meaning } \\
\text { distorted }\end{array}$ & Enabler & Message changed \\
\hline $\begin{array}{l}\text { Levels of Absorptive } \\
\text { Capacity \& Technological } \\
\text { Capability }\end{array}$ & $\begin{array}{l}\text { Same } \\
\text { knowledge } \\
\text { level }\end{array}$ & $\begin{array}{l}\text { Same } \\
\text { knowledge } \\
\text { level }\end{array}$ & $\begin{array}{l}\text { Matching skillsets } \\
\text { Education level }\end{array}$ & $\begin{array}{l}\text { Matching level } \\
\text { of capabilities }\end{array}$ \\
\hline $\begin{array}{l}\text { Development of Skilled } \\
\text { Human Resources }\end{array}$ & $\begin{array}{l}\text { Employee gains } \\
\text { valuable skillsets } \\
\text { Employer at good } \\
\text { position }\end{array}$ & $\begin{array}{l}\text { Skilful } \\
\text { employees }\end{array}$ & $\begin{array}{l}\text { Employees } \\
\text { own good } \\
\text { skillsets }\end{array}$ & $\begin{array}{l}\text { Potential of human } \\
\text { resources }\end{array}$ & $\begin{array}{l}\text { Employee gains } \\
\text { valuable skillsets }\end{array}$ \\
\hline Economic Advancement & $\begin{array}{l}\text { Time and money } \\
\text { for training }\end{array}$ & $\begin{array}{l}\text { Financial } \\
\text { support by } \\
\text { government }\end{array}$ & $\begin{array}{l}\text { Financial } \\
\text { support by } \\
\text { government }\end{array}$ & Technical training & $\begin{array}{l}\text { Employees } \\
\text { training }\end{array}$ \\
\hline
\end{tabular}

Human resources are one of the key components in an organisation. Human capital can be considered as the set of marketable skills workers in which a variety of investments are made, such as training and education. With adequate investment in these sectors, potential of human resources will improve and are marketable. A technology transfer is a good resource for cultivating human capital in developing countries like Malaysia. Once employees gain valuable skillsets and knowledge of technology transfer, organisation will have a better position in the market and also improve the successful technology transfer in MRT project.

Economic advancement influenced technology transfer in Malaysia's MRT project because capital funding is the main consideration when applying technology transfer in the project. The organisation has to balance between the cost of technology transfer and the return from the project because huge investment in technology transfer would reduce the profitability of the project. A good economic status of the country implies that the government is financially strong to provide subsidies, tax incentives or financial support for the MRT project. Support from government would definitely reduce financial burden of the organisation and promote the application of technology transfer in the project. Furthermore, organisation's vision and long-term goals may also influence technology transfer in MRT project.

\section{Conclusion}

Based on the results obtained from data analysis, advance technologies that transferred in Malaysia's MRT project include tunnelling work, signalling, train assembly, train control, track work, underground work, rail work and stair tower. Tunnelling and underground works are the main segments that involved in technology transfer in the MRT project because Klang Valley MRT is the first underground MRT in Malaysia. These advance technologies were transferred into Malaysia's MRT project from few developed countries such as Germany, Japan, Korea, France, Australia, Italy and Canada. Developed countries mentioned above owned good and advance construction technologies in MRT.

The factors are organisational capability, relational capability, communication, levels of absorptive capacity and technological capability, development of skilled human resources and economic advancement. Besides that, respondents of this study also provide few more factors that affecting technology transfer in MRT project which are company's vision, company's long term goals, government funding and tax incentives.

A well-structured and supportive organisation is essential in technology transfer in order to obtain maximum benefit return from technology transfer. Besides that, relational capability is another factor influencing technology transfer in MRT project. Good relationship between two parties who involved in technology transfer in MRT project is important for the success of technology transfer.

Communication influences technology transfer because technology transfer involves conversation and transferring of knowledge. According to all the respondents, without similar language, meaning of messages might be distorted. If the meaning of messages is distorted, this will easily causes failures of technology transfer in MRT project. Transferee might not able to adopt technologies that are transferred from transferor in MRT project due to the lack of understanding of technologies that transferred.

Human capital can be considered as the set of marketable skills workers in the organisation. Technology transfers are a good resource for cultivating human capital in developing countries like Malaysia. Respondents from MMC-Gamuda Sdn. Bhd. explained that once employees gain valuable skill sets and knowledge through technology transfer, organisation 
will have a better position in the market and also improve the successful technology transfer in MRT project. Hence, development of skilled human resources is one of the factors influencing technology transfer in MRT project.

The authors would like to thank the Geran Penyelidikan Kontrak Khas 2015 (U432), Office for Research Innovation, Commercialization and Consultancy Management (ORICC) The authors would like to thank the Geran Penyelidikan Kontrak Khas 2015 (U432), Office for Research Innovation, Commercialization and Consultancy Management (ORICC) and Centre for Graduate Studies (CGS) of Universiti Tun Hussein Onn Malaysia (UTHM) who was supported the research paper.

\section{References}

1. A. C Inkpen, and A. Dinur. The Transfer and Management of Knowledge in the Multinational Corporation: Considering Context. United States: Carnegie Bosch Institute, (1998)

2. G. Ofori. Construction industry development: role of technology transfer. Construction Management and Economics, vol. 12 no. 5 pp 379-392 (1994)

3. R. Omar, R. Takim, and A. H. Nawawi. Importing International Technology Through International Technology Transfer (ITT) Projects in Construction: Synthesis of ITT Projects Models, pp 66-67 (2008)

4. J. K. C. Chen, W. H. Chiu, S. F. L. Kong, and L. Y. T. Lin. Evaluating Global Technology Transfer Research Performance, vol. 7 no.10 pp 361-366, (2010)

5. K. A. K. Devapriya and S. Ganesan. Technology Transfer Subcontracting in Developing Countries through. Building Research \& Information, vol. 30 no. 3 pp 171-182 (2002)

6. P. Kenyon. MMC-Gamuda orders six TBMs from Herrenknecht, [Online]. Available: http://www.tunneltalk.com/Kuala-Lumpur-MRTApr12-Herrenknecht-takes-six-TBM-order-forKuala-Lumpur-MRT.php (2012)

7. A. N. Ee. Klang Valley MRT offset scheme to contribute RM3.5b. [Online]. Available: http://www.thesundaily.my/news/880072 (2012)

8. O. K. Ting. SMEs in Malaysia: Pivotal Points for Change [Online]. Available: http://www.mca.org.my (2004)

9. K. Stuti IAS, Overcoming Barriers to Innovation for Indian SMEs. Ministry Small Scale Industries, New Delhi, India (2005)

10. M. A. Burhanuddin, F. Arif, , V. Azizah and A. S. Prabuwono. Barriers and Challenges for Technology Transfer in Malaysian Small and Medium Industries. International Conference on Information Management and Engineering, pp 258261 (2009)

11. Y. Palansamy. Citing 'onsite challenges', $M R T$ Corp claims delay unavoidable. [Online]. Available:
[Online]. Available: http://www.themalaymailonline.com, (2015)

12. N. W. Coppola. Tools for the Innovation Agenda: A Case Study of Communication in Technology Transfer and Diffusion, pp 231-235 (2006)

13. T. K. Wie. The major channels of International Technology Transfer to Indonesia: An Assessment. Conference on Catch-Up Growth and Technology Transfer, University of Groningen, Groningen (2003)

14. D. Zimmerman, T. Yohon, and L. Stapel. Using Theory to Enhance Technology Transfer and Diffusion of Innovations (2007)

15. J. N. Mostert. The Practise of Technology Transfer. Portland International Conference on Management of Engineering \& Technology, pp 2281-2286, (2008)

16. H. Nakamura, T. Kubota, M. Furukawa, and T. Nakao. Unified Construction of Running Track Tunnel and Crossover Tunnel for Subway by Rectangular Shape Double Track Cross-Section Shield Machine. Tunnelling and Underground Space Technology, vol. 18 no. 2-3, pp 253-262 (2003)

17. H. Soejima Railway Technology in Japan Challenges and Strategies. Railway Technical Research in Asia, vol 36, pp 4-13 (2003)

18. P. Kenyon. MMC-Gamuda orders six TBMs from Herrenknecht, (2012). [Online]. Available: http://www.tunneltalk.com/

19. B. C. Peng, and N. Chen. Energy Saving Strategies in Mass Rapid Transit Systems pp 272-277 (2014)

20. E. D. Larson. A review of life-cycle analysis studies on liquid biofuel systems for the transport sector. Energy for Sustainable Development, vol 10 no 2, pp 109-126, (2006)

21. J. Hill, E. Nelson, D. Tilman, S Polasky, and D. Tiffany. Environmental, economic, and energetic costs and benefits of biodiesel and ethanol biofuels. National Academy of Science of USA, vol 103 no 30 pp 11206-11210 (2006)

22. Y. S. Fang, C. C. Kao, and Y. F. Shiu. Double-O Tube Shield Tunneling for Taoyuan International Airport Access MRT. Tunneling and Underground Space Technology, vol 30 pp 233-245 (2012)

23. S. Chang, K. Y Chang, and K. H Cheng. The Study of Urban Track Transportation Environment Noise and Vibration Prevention: Floating Slab Track of Taipei MRT. WIT Transactions on the Built Environment, vol 111 pp 203-214 (2010)

24. U. G. Jr. Tomas. The Influence of Megatren System on Ridership in Metro Manila. International Journal of u- and e- Service, Science and Technology, vol 8 no. 1, pp 91-104, (2015).

25. S. W. Dewy. Jokowi leads MRT ground-breaking ceremony. (2013). [Online]. Available $\mathrm{http}: / /$ www.thejakartapost.com/news/ 
26. J. Grogan. The MRT Jakarta Project. 40th Year of ASEAN - Japan Friendship and Cooperation, pp 12-13 (2013)

27. K. Barrow. Jakarta Metro Civil Works Contracts Signed. [Online]. Available: http://www.railjournal.com/

28. A. Banerjee, and S. Chaudhury. Statistics without tears: Populations and Samples. Ind Psychiatry J, vol. 19 no. 1 , pp 60-65 (2010)
29. F. Gomez, T. Daim and R. Jorge. Characterization of the Relationship between Firms and Universities and Innovation Performance: The Case of Colombian Firms. Journal of Technology Management and Innovation, vol. 9 no. 1 70-83, (2014)

30. J. Keyton. Communication and Organisational Culture: A Key to Understanding Work Experience. Thousand Oaks, CA: Sage

(2011) 